\title{
Paint Relics on Middle Age Building Stones as Proxies of Commercial Routes and Artistic Exchanges: A Multi-Analytical Investigation
}

\author{
Simona Scrivano *(1), Laura Gaggero 1 and Elisa Volpe \\ Department of Earth, Environment and Life Sciences, University of Genoa, 16132 Genoa, Italy; \\ gaggero@dipteris.unige.it (L.G.); foxy25@hotmail.it (E.V.) \\ * Correspondence: simona.scrivano@edu.unige.it; Tel.: +39-010-353-58301
}

Received: 23 August 2019; Accepted: 25 October 2019; Published: 28 October 2019

\begin{abstract}
Fifty-four pieces out of 356 marble pieces deriving from the decorative and architectonic apparatus of the medieval monastic complex of S. Francesco of Castelletto (Genoa, Italy) preserve traces of varicolored paint layers. Microscopic samples of green, blue, red, pink, white, and yellow paint relics were collected by scalpel and analyzed by means of Scanning Electron Microscope coupled with Energy Dispersive Spectroscopy (SEM-EDS), $\mu$-Raman, and Fourier Transform Infra-Red Spectroscopy with Attenuated Total Reflection (FTIR-ATR), to characterize pigments and binders. The combined results from the different techniques allowed verification that stone decoration in Genoa during the Middle Ages encompassed a calcite groundwork and the use of a mixture of oils and proteins (probably egg) to apply pigments. The assemblage of impurities within the pigment has been correlated with the provenance sites along the commercial continental (Hungary and France) and maritime (Sardinia, Cyprus, or Veneto) routes between the 13th and 15th centuries. Moreover, the investigation of the painted layer improved the characterization of the decorative techniques in use in Genoa during the Middle Ages.
\end{abstract}

Keywords: polychromies; pigments; medieval commercial routes; painted marble; architectural ornaments

\section{Introduction}

Studies over the last 50 years have demonstrated that the neoclassical perspective of absolute white marble sculptures from antiquity to modern times is not correct. Nowadays, it is well known that antique cultures (Egyptians, Greeks, and Romans) used to apply naturalistic polychromatic paint layers onto marble sculptures, although their symbolic value has still not been definitively assessed [1]. The use of paint on stone surfaces is also reported for the Middle Ages [2]. Here, bright colors not necessarily associated with naturalistic appearances [3] characterize architectural surfaces (portals, bas-reliefs, capitals, and columns, etc.), emphasizing the function of the building. In this perspective, the selection of pigments was also significant. In fact, depending on rarity and value, some pigments (e.g., natural ultramarine) were used only to represent deities and royalty.

Several theoretical essays of the Middle Ages (Pseudo Eraclio, Boileau, Cennini) report the habits of Middle Age painters and their know-how concerning materials used in art, stating that painting on stones was a minor art. Two treatises on the 13th century (Pseudo Eraclio, Boileau) report that polychromies on stone were the result of a succession of two (or three) ground layers of lead white, on top of which pigments dispersed in oil were applied [4]. Later on, Cennino Cennini (15th century) described the technique in use since Giotto, stating that pigments, usually obtained from minerals and rarely by alchemic processes, were reduced to powder and mixed with an oleic binder to be applied on stone surfaces, and were in use in the northern regions (Germany [5]). These technical essays report 
the pigment origin (provenance or alchemic process), and that diverse pigments were recommended for different substrate and artistic techniques.

Case studies in literature show that the practice does not always match the theory. In fact, except for sporadic textbook examples, quoting lead white dispersed in oil [6], Middle Age polychrome stones all over Europe had different recipes for ground layer preparations. The literature reports several cases of preparations made with lead white dispersed in egg or animal glue [7-9], and numerous examples of calcium carbonate [10-13] or gypsum-based [14,15] ground layers. Moreover, rare cases of plain animal glue preparation or even the absence of groundwork are reported [16-18]. A better correspondence with theoretical essays was noted for binders of pictorial layers, which are usually pure oleic materials [8] or are mixed with protein-based materials [9], although there are isolated exceptions [16]. The cases in literature help in interpreting the variety of techniques used in Middle Age colored stonework. In particular, Edwards [12] hypothesizes a technical evolution of ground layers from the Roman know-how (i.e., the use of calcite ground layers) to Middle Age habits. On the other hand, Weeks [19] testifies that, in some cases, different techniques were adopted for different purposes: the white lead ground layer was applied on stone sculptures, while architectonic marble pieces were painted on directly.

Following these rationales, this study focused on the characterization of color traces preserved upon a cluster of 54 Middle Age marble pieces. The pieces, part of a group of 356 marble fragments excavated at the site of the gothic monastic complex of S. Francesco of Castelletto (Genoa, Italy), were catalogued: the typological and stylistic analysis helped in defining them as Middle Age ornamental and architectonic pieces pertaining to the first phase of edification of the long-lost monastic complex [20]. The number of colored surfaces in pieces belonging to diverse parts of the complex (church façade, cloisters, etc.) highlights the fact that it was characterized by polychromatic surfaces. Furthermore, support came from other examples of coeval buildings with painted stone surfaces in Genoa, e.g., the façade of the S. Lorenzo cathedral [3].

Among the 54 catalogued polychrome pieces, nine decorative and architectural fragments belonging to the façade of the church and to the ornamentation of one of the three cloisters were chosen for further analysis. The selected fragments showed the five colors (i.e., blue, red, green, black, yellow) that recurred with different shades on the whole set of Middle Age pieces. The purpose of this investigation is the characterization of the pigments used in stone polychromies, at deepening the knowledge about techniques used in the Middle Ages, and at inferring their geographic/geologic provenance on the grounds of mineralogical associations. In particular, this information helped in the reconstruction of art materials that were traded in Genoa during the Middle Ages.

\section{Materials and Methods}

\subsection{Materials}

The study of the pictorial layers was carried out on paint relics on nine marble fragments belonging to the Middle Age phase of the church, and stylistically dated $c$. the second half of the 13th century (Figure 1; Table 1). Their function ranged from architectonic (e.g., pillar sections) to purely decorative (e.g., ornate arches), and originally provided the effect of colorful surfaces. 


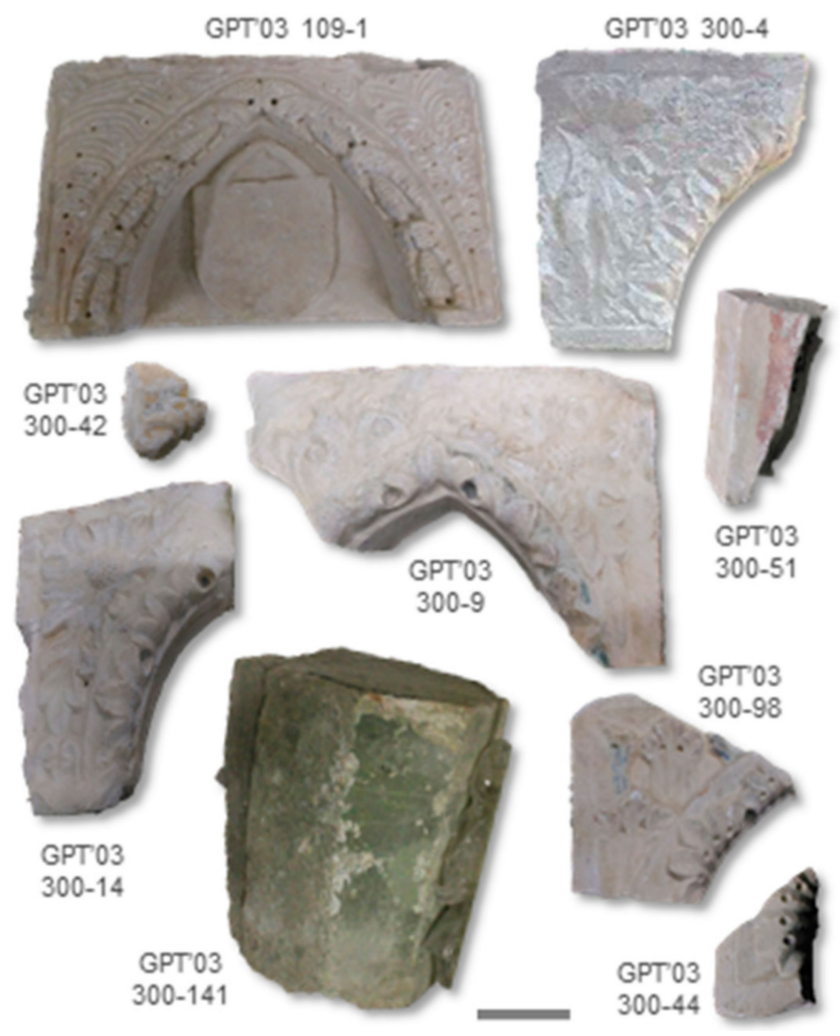

Figure 1. Nine of the representative studied fragments. Scale bar $10 \mathrm{~cm}$. The photographs are courtesy of the Superintendence of Archaeology, Fine Arts, and Landscape for the metropolitan city of Genoa and the provinces of Imperia, La Spezia, and Savona (Italian ministry of Cultural Heritage). Partial or total reproduction is forbidden without prior (written) permission.

The remnants of three different shades of blue were studied on three single sided sculpted fragments of double arches with phytomorphic decorations (leaves and shoots) (i.e., GPT'03 300-9, GPT'03 300-44, and GPT'03 300-98). Four shades of red were studied on fragments of two double arches with flower decorations (pink, GPT'03 300-4a; orange pink, GPT'03 300-14), a section of jamb from an arched portal or windows with plain decoration (carmine red, GPT'03 300-51), and a bas-relief niche with a coat of arms and grapes (light pink, GPT'03 109-1a). The same piece of bas-relief niche presented remnants of violet-black paint on the grapes (GPT'03 109-1b). Yellow patina and paint traces were characterized on a section of jamb of an arched portal or windows with phytomorphic decoration (GPT'03 300-42a), while a pillar section showed a sequence of green paint layers (GPT'03 300-141). Also, the marble surfaces (GPT'03 300-4c and GPT'03 300-42b) and ground layers were analyzed (GPT'03 300-4).

The study was carried out with a multi-technique approach (Table 1) on microscopic samples (about $1-3 \mathrm{~mm}^{3}$ ) collected by lancet. Samples were further subdivided so they could be analyzed with different instruments. For each sample, one part was used as collected (FTIR-ATR analysis), one part was embedded in epoxy resin to make cross sections (microscopy and Raman spectroscopy), and, finally, one part was mounted with carbon tape on a stub and was then coated to be conductive under SEM-EDS analysis. 
Table 1. Scheme of the analyses performed on the selected paint samples.

\begin{tabular}{|c|c|c|c|c|c|c|}
\hline Sample & Typology & Color & $\begin{array}{c}\text { USB } \\
\text { Microscopy }\end{array}$ & SEM-EDS & $\mu$-RAMAN & FTIR-ATR \\
\hline 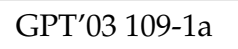 & pictorial layer & light pink & $x$ & & $\mathrm{x}$ & $x$ \\
\hline 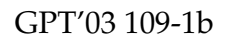 & pictorial layer & violet-black & $x$ & & $x$ & $x$ \\
\hline GPT'03 300-4a & pictorial layer & pink & $x$ & $\mathrm{x}$ & & \\
\hline $\mathrm{GPT}^{\prime} 03$ 300-4b & ground layer & white & $x$ & $x$ & & \\
\hline $\mathrm{GPT}^{\prime} 03$ 300-4c & marble & & $x$ & $x$ & & $x$ \\
\hline 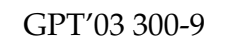 & pictorial layer & blue & $x$ & $x$ & $x$ & $x$ \\
\hline GPT'03 300-14 & pictorial layer & orange pink & $x$ & & $\mathrm{x}$ & \\
\hline GPT'03 300-42a & pictorial layer & yellow & $x$ & $x$ & $x$ & $x$ \\
\hline $\mathrm{GPT}^{\prime} 03$ 300-42b & marble & & $x$ & $x$ & & $x$ \\
\hline GPT'03 300-44 & pictorial layer & blue & $x$ & & $\mathrm{x}$ & $x$ \\
\hline $\mathrm{GPT}^{\prime} 03$ 300-51 & pictorial layer & red & $x$ & $x$ & $x$ & $x$ \\
\hline GPT'03 300-98 & pictorial layer & blue & $x$ & $x$ & $x$ & $x$ \\
\hline GPT'03 300-141 & pictorial layer & green & $x$ & $x$ & $x$ & $x$ \\
\hline
\end{tabular}

\subsection{Methods}

\subsubsection{Mesoscopic Study of the Surface of the Paint Layers}

Paint traces were identified and documented in-situ at the repository with a digital portable microscope (Dinolite AM-7013MZT; Dino-Lite Europe IDCP B.V., Naarden, The Netherlands). The 50× to $200 \times$ magnification allowed the study of the painting layer characteristics and the stylistic details, including the brush strokes.

\subsubsection{Scanning Electron Microscopy Coupled with EDS}

The SEM analyses were carried out using a Tescan Vega 3 LM scanning electron microscope equipped with an Apollo $X$ detector and a Microanalysis TEAM Energy Dispersive Spectrometry (SEM/EDS: TESCAN, Brno, Czech Republic), installed at the Department of Earth Environment and Life Sciences (DISTAV) of the University of Genoa, Italy. Microphotographs were acquired with an optimized ratio between back scattered and secondary electrons in order to preserve chemical and topographic information. The EDS analysis were performed with an electron beam power of $20 \mathrm{kV}$ and a working distance of $15 \mathrm{~mm}$. The data were acquired under high-vacuum conditions on graphite sputter-coated three-dimensional samples.

\subsection{3. $\mu$-Raman Spectroscopy}

The $\mu$-Raman measurements were performed on three-dimensional micro-samples and on cross sections, at DISTAV, University of Genoa, with a Horiba Jobin-Yvon XploRA_Plus single monochromator spectrometer (HORIBA Ltd., Kyoto, Japan), equipped with 2400 groove/mm grating and coupled with an Olympus BX41 microscope (Olympus Italia S.r.1., Segrate, Italy; microscope objectives, 10× and 100×; spatial resolution, $2 \mu \mathrm{m}$ ). A solid-state laser source at $532 \mathrm{~nm}$ (maximum power $20 \mathrm{~mW}$ ) was used for excitation. The spectra were collected between $80-1800 \mathrm{~cm}^{-1}$ and $3000-3400 \mathrm{~cm}^{-1}$, but only the useful range is herein reported. The instrumental spectral resolution was $\sim 2 \mathrm{~cm}^{-1}$, guaranteeing a peak position accuracy of $0.56 \mathrm{~cm}^{-1}$. Neutral density filters were employed to keep the laser power at a low level $(0.05-1 \mathrm{~mW})$ on the samples to avoid laser-induced transformations. The spectra were collected with repeated acquisitions (10-15) of 3-10 s, according to signal to noise ratio. The spectrometer was calibrated on a pure silicon wafer (Raman peak at $520.5 \mathrm{~cm}^{-1}$ ). Peaks were identified and interpreted based on specialized databases reporting peak listings of minerals and art supplies in use from antiquity until the present day [21-24]. 


\subsubsection{Fourier Transform Infra-Red (FTIR) Spectroscopy}

FTIR spectroscopy was performed using a Perkin Elmer Spectrum 65 FTIR Spectrometer (Perkin Elmer, Waltham, MA, USA; spectral resolution of $0.5 \mathrm{~cm}^{-1}$ ) equipped with an attenuated total reflection (ATR) accessory (diamond crystal), a KBr beam-splitter and a deuterated triglycine sulfate (DTGS) detector. All spectra were recorded with 60 scans from 4000 to $600 \mathrm{~cm}^{-1}$. Micro fragments of the samples were put directly in contact with the ATR diamond crystal, making sure that the outermost painted layer was correctly placed to be analyzed. FTIR absorption peaks were identified and interpreted according to databases specialized in artistic materials [21,24].

\section{Results}

\subsection{Blue}

Traces of a thin layer (about $0.1 \mathrm{~mm}$ ) of blue paint (Figure 2a) were detected in the floral decorated internal rim of the fragment of double arch GPT'03 300-9. Surface analysis demonstrated deep blue grains dispersed in a lighter colored matrix (Figure 2a). The study of their size and shape (i.e., sharp edges) support the fact that the pigment is a mineral phase. Micro-textural analysis under SEM suggests the presence of an organic binder visible between the pigment particles (Figure 2d). The pigment was characterized by FTIR spectroscopy (Figure 2g; absorptions at 950, 1416, and $1496 \mathrm{~cm}^{-1}$ ) and $\mu$-Raman (Figure 2( $\left.\mathrm{h}_{\mathrm{i}}\right)$; peaks at 145, 180, 250, 405, 767, and $839 \mathrm{~cm}^{-1}$ ) as azurite. Associated with the azurite blue grains, $\mu$-Raman highlighted rare black grains of carbonaceous material (Figure $2\left(\mathrm{~h}_{\mathrm{iv}}\right)$; broad peaks at 1325 and $1580 \mathrm{~cm}^{-1}$ ); and light green grains of copper chlorides (Figure 2( $\mathrm{h}_{\mathrm{iii}}$ ); atacamite, peaks at 151, 255, 508, 821, 913, and $976 \mathrm{~cm}^{-1}$; and clinoatacamite, peaks at 120, 138, 515, and $790 \mathrm{~cm}^{-1}$ ). EDS analyses evidenced accessory grains of rare earth phosphates ( $, \mathrm{Ce}, \mathrm{Sm}, \mathrm{Pr}, \mathrm{La}$ ) interpreted as monazite, and sporadic micro-grains of pyromorphite ( $\mathrm{Pb}$ phosphate).

Traces of thin blue layers of azurite $(0.08 \mathrm{~mm}$ thick) also occur in two fragments of the double arches GPT'03 300-44 and GPT'03 300-98. Both samples show mineral grains of blue pigment, locally altered to green (Figure $2 b, c, e)$. Back scattered electron images suggest an organic binder between the particles of the pigment (Figure 2f), supported also by FTIR analysis (Figure 2g). The $\mu$-Raman analysis (Figure $2 \mathrm{~h}$ ) allowed characterization of the associated grains as malachite (green grains, peaks at 152, 177 , and $431 \mathrm{~cm}^{-1}$ ), mixite (dark green grains, peaks at 170, 226, 318, 397, 426, 475, and $854 \mathrm{~cm}^{-1}$ ), and carbonaceous material (broad peaks at 1325 and $1580 \mathrm{~cm}^{-1}$ ). Also, rare grains of barite (Ba, S) were found with EDS analysis. A peak at $987 \mathrm{~cm}^{-1}$ in the FTIR spectrum of GPT'03 300-44 (Figure 2g) could be caused by silicate impurities, probably due to the burial phase, or to phosphate groups often present in the mixite structure [25].

\subsection{Red}

Traces of a light shade of orange-pink pictorial layer ( $0.2 \mathrm{~mm}$ thick; Figure $3 \mathrm{~d})$ from a double arch decorated with flowers and leaves (GPT'03 300-14) were addressed. The surface analysis evidenced a pictorial layer uniform in grain size and texture, although the color ranged from darker tones of red to light orange-pink (Figure 3a). The $\mu$-Raman spectrometry (Figure 3h) allowed characterization of the main pigment as red ochre through its peaks at 224, 245, 293, 410, and $612 \mathrm{~cm}^{-1}$ (hematite) and 526 and $677 \mathrm{~cm}^{-1}$ (magnetite). In addition, quartz impurities (peaks at 125, 200, 262, 354, and $463 \mathrm{~cm}^{-1}$ ) were identified in the pigment, as in sample GPT'03 300-4a.

Carmine red brush strokes occurred on a concave face of the section of jamb of the arched portal or window GPT'03 300-51. The surface analysis by optical microscopy highlighted high homogeneity in the pictorial layer (Figure 3b). Based on the results of SEM-EDS (Figure 3e), FTIR (Figure 3g), and $\mu$-Raman (Figure $3 \mathrm{~h}$ ) analyses, the pigment was interpreted as red ochre (hematite + clays; hematite peaks at 224, 245, 293, 410, and $612 \mathrm{~cm}^{-1}$; and silicate absorptions at 1032 and $3700 \mathrm{~cm}^{-1}$ ). EDS analysis also allowed the identification of rare grains of barite $(\mathrm{Ba}, \mathrm{S})$ as accessory mineral. 

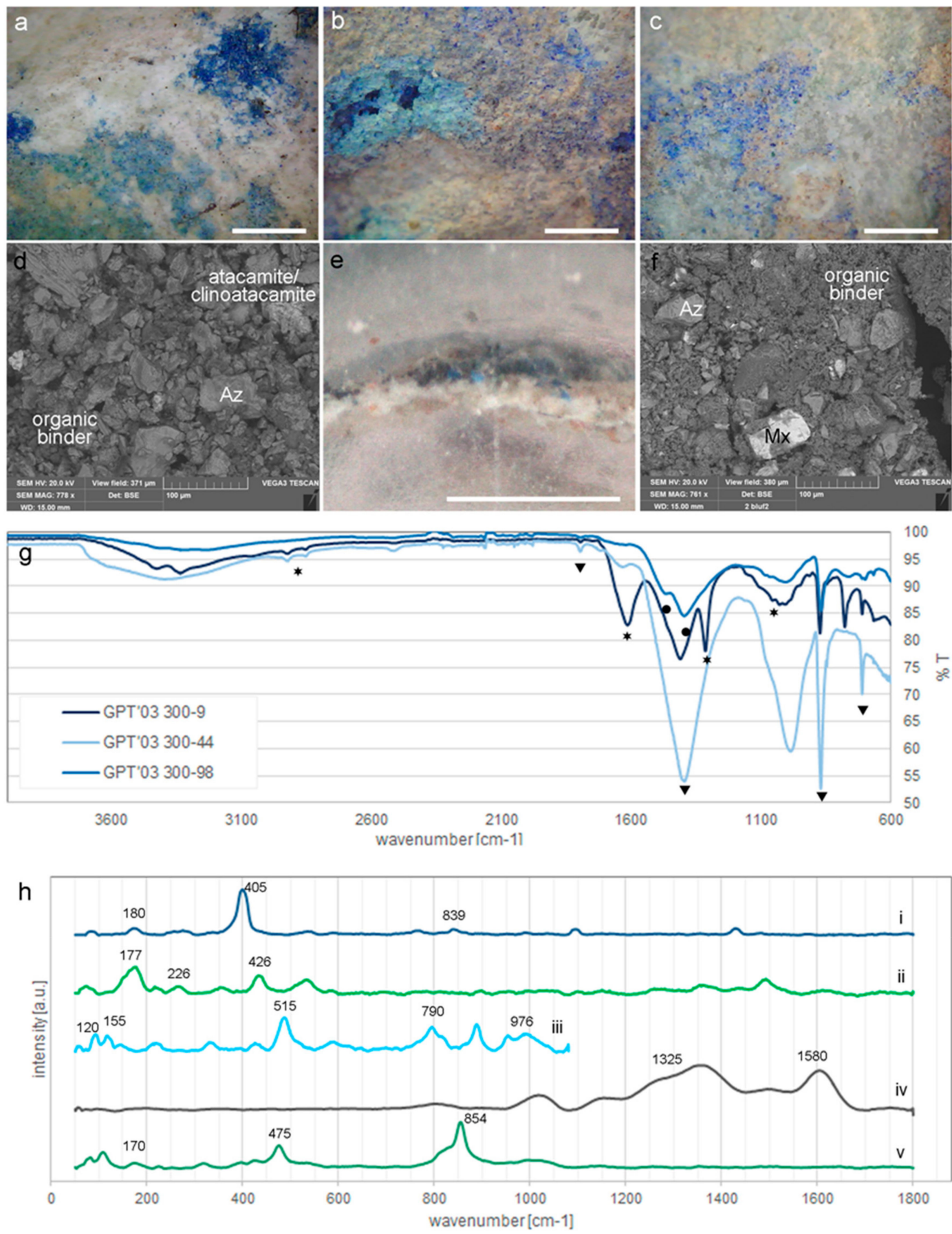

Figure 2. Blue: (a-c) Microphotographs of the surface of the samples. Scale bar $1 \mathrm{~mm}$. (a) GPT'03 300-9. (b) GPT'03 300-44. (c) GPT'03 300-98. (d) Back scattered electron image of GPT'03 300-9. Az = azurite. (e) Cross section of GPT'03 300-44. Scale bar 1 mm. (f) Back scattered electron image of GPT'03 300-98. $\mathrm{Az}=$ azurite. (g) FTIR ATR spectra. * indicates the peaks linked with the organic fraction, $\mathbf{\Delta}$ indicates the peaks connected with calcite due to the marble substrate, and $\bullet$ indicates the peaks linked with azurite. (h) Raman spectra. i = azurite; ii = malachite from GPT'03 300-44; iii = atacamite/clinoatacamite from GPT'03 300-9; iv = carbon black from GPT'03 300-9; and v = mixite from GPT' 300-44 and GPT'300-98. 

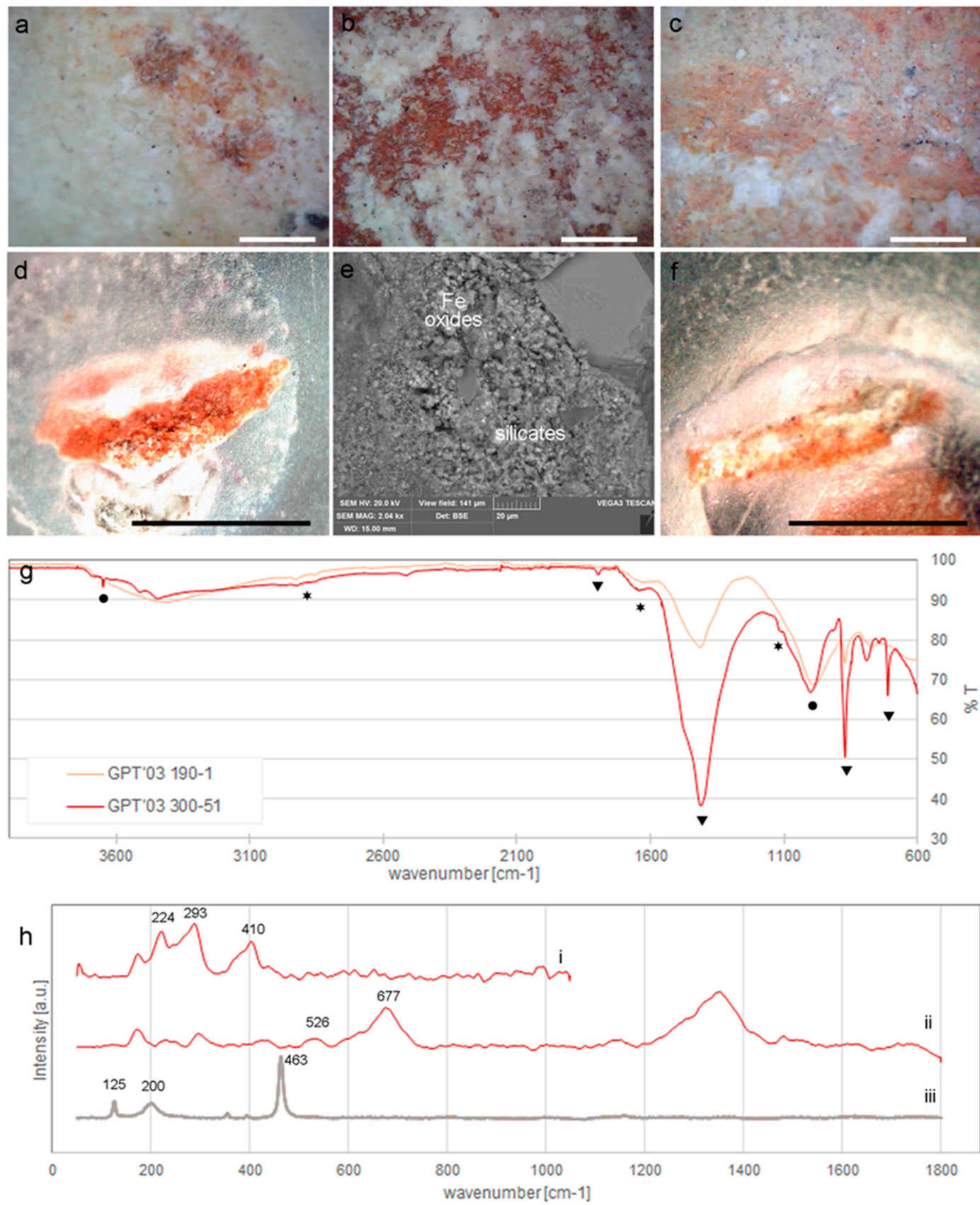

Figure 3. Red: $(\mathbf{a}-\mathbf{c})$ Microphotographs of the surface of the samples. Scale bar $1 \mathrm{~mm}$. (a) GPT'03 300-14. (b) GPT'03 300-51. (c) GPT'03 109-1. (d) Cross section of GPT'03 300-14. Scale bar $1 \mathrm{~mm}$ (e) Back scattered electron image of GPT'03 300-51. (f) Cross section of GPT'03 109-1. Scale bar $1 \mathrm{~mm}$. (g) FTIR ATR spectra. * indicates the peaks linked with the organic fraction, $\boldsymbol{\Delta}$ indicates the peaks connected with calcite, and $\bullet$ indicates the peaks linked with silicates associated with hematite in the ochre. (h) Raman spectra. $\mathrm{i}=$ hematite from GPT'03 300-51; ii = hematite + magnetite from GPT'03 300-14; iii = quartz from GPT'03 300-14.

A light pink paint layer ( $0.15 \mathrm{~mm}$ thick; Figure $3 \mathrm{f})$ also characterizes part of the phytomorphic decorations of the bas-relief arched niche GPT'03 109-1a. Isolated rare darker grains (Ø $0.05 \mathrm{~mm})$, possibly acting as color centers, are dispersed in the paint layer (Figure 3c). The pigment was identified as burnt sienna (peaks at 211, 283, and $388 \mathrm{~cm}^{-1}$ ) by $\mu$-Raman analyses (Figure $3 \mathrm{~h}$ ). 


\subsection{Black}

The sculpted grapes cropping up from the racemes in GPT'03 109-1b preserve traces of violet-black color. In-situ microscopy evidenced a bluish grey ground-layer with small irregular black particles as color cores (Figure $4 \mathrm{a}, \mathrm{c}$ ). The $\mu$-Raman spectrum (Figure $4 \mathrm{f}$ ) allows identification of the pigment grains as carbon black (broad peaks at 1333 and $1604 \mathrm{~cm}^{-1}$ ).
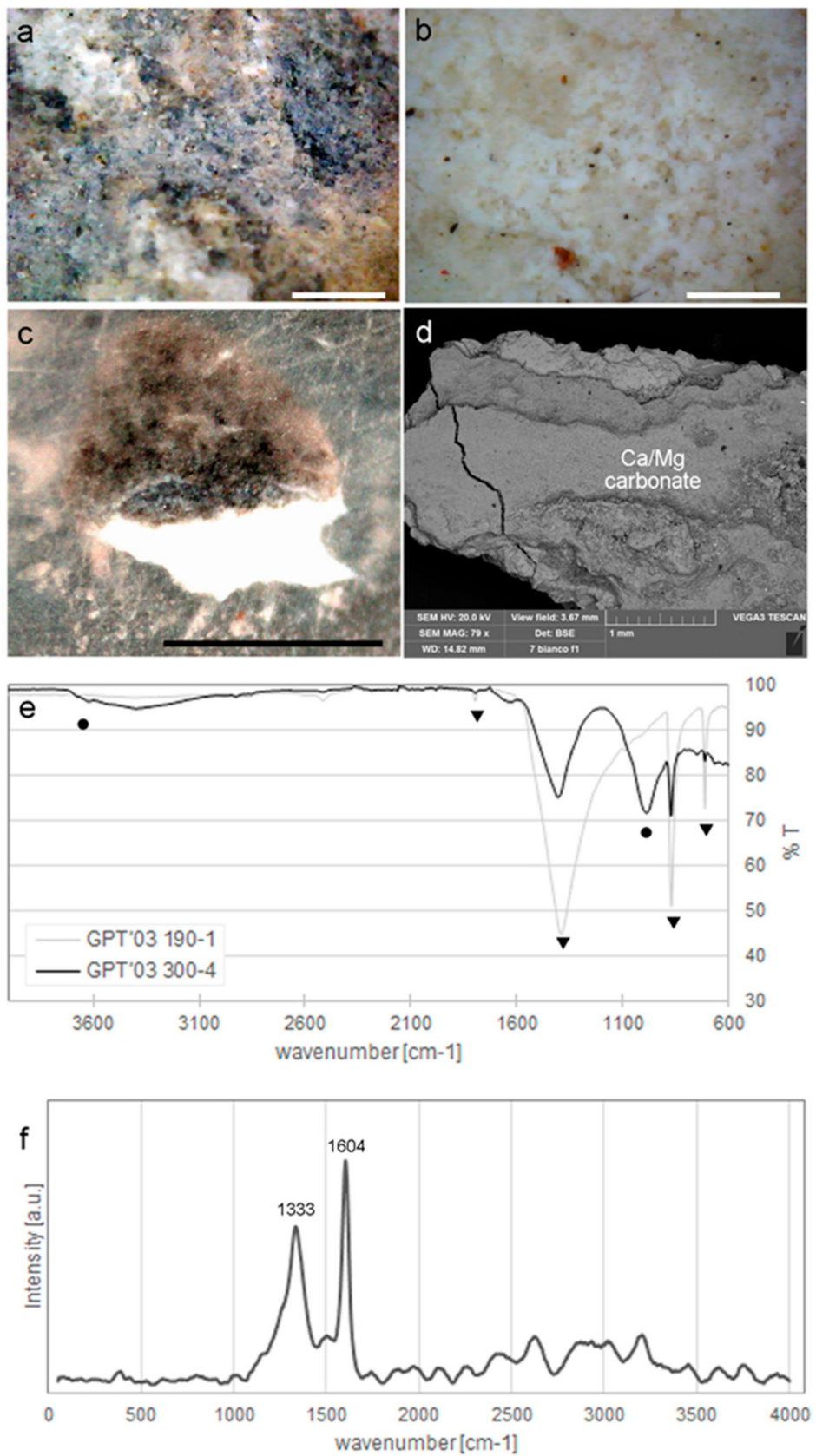

Figure 4. Black paint layer and white ground layer: $(\mathbf{a}, \mathbf{b})$ Microphotographs of the surface of the samples. Scale bar 1 mm. (a) GPT'03 109-1. (b) GPT'03 300-4. (c) Cross section of GPT'03 109-1. (d) Back scattered electron image of the succession of three ground layers in GPT'03 300-4. (e) FTIR ATR spectra. $\Delta$ indicates the peaks connected with calcite and - indicates the peaks linked with silicates. (f) Raman spectra of carbon black. 


\subsection{Yellow}

A fragment of a decorated jamb of arched portal or window (GPT'03 300-42a) showed remnants of a yellow paint layer on at least two sides. The surface exhibited a homogeneous thin layer (Figure 5a). Microtextural analysis showed microscopic pigment powders $(1-10 \mu \mathrm{m})$ dispersed in an organic binder (Figure $5 b, c)$. The pigment is identified as a lead-based pigment (probably massicot; peaks at 144 and $283 \mathrm{~cm}^{-1}$ ) mixed with yellow ochre (goethite peaks at 303,430, and $675 \mathrm{~cm}^{-1}$ and EDS peaks of $\mathrm{Fe}, \mathrm{Al}$, and Si) (Figure 5f). FTIR absorption bands at 1032 and $3700 \mathrm{~cm}^{-1}$ confirmed the presence of silicates (Figure 5e). The $\mu$-Raman (Figure 5f) also allowed the identification of gypsum (peaks at 1011 and $\left.1037 \mathrm{~cm}^{-1}\right)$. Furthermore, EDS evidenced rare barite $(\mathrm{Ba}, \mathrm{S})$ grains, probably related with the ochre.
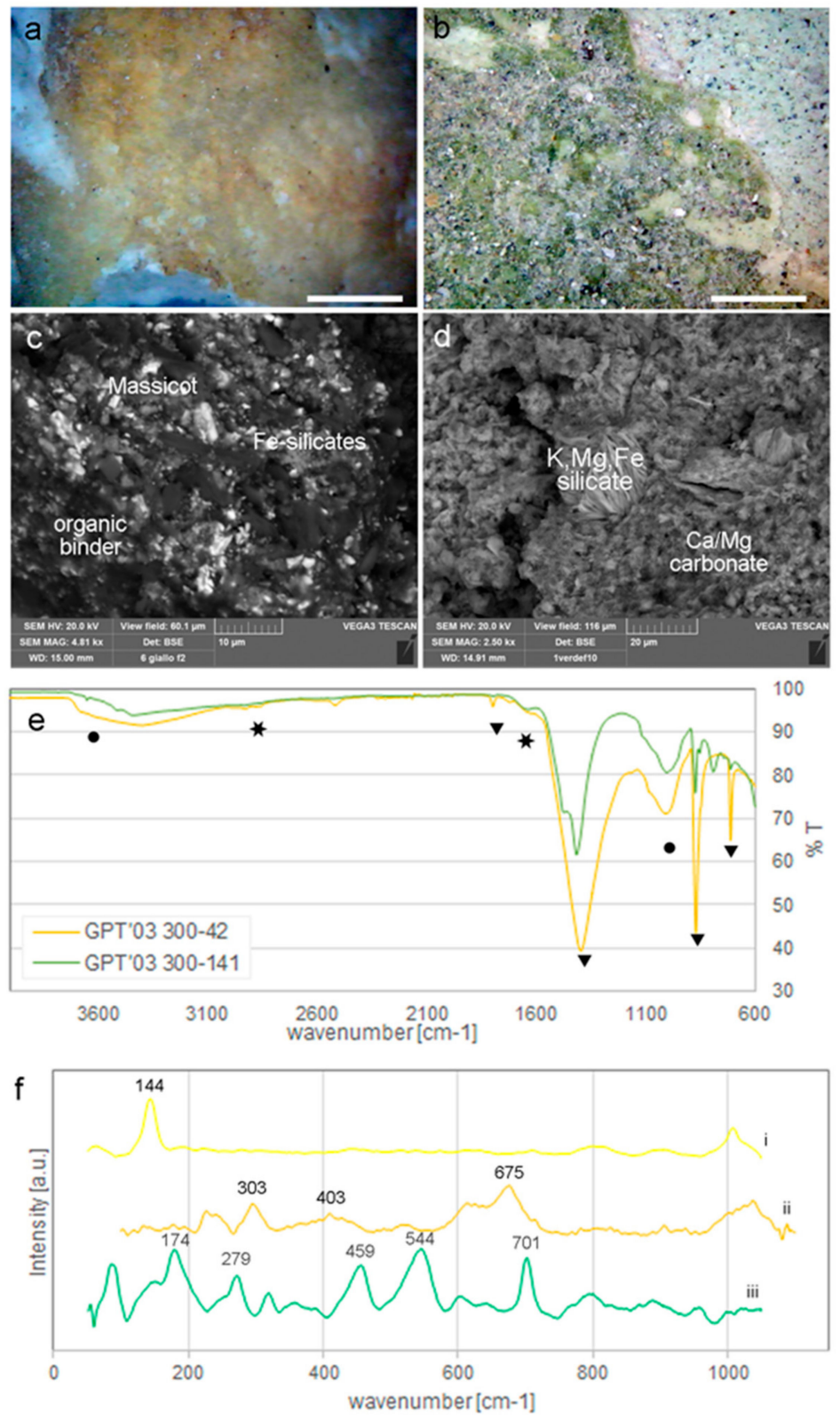

Figure 5. Yellow and Green: (a,b) Microphotographs of the surface of the samples. Scale bar $1 \mathrm{~mm}$. (a) GPT'03 300-42. (b) GPT'03 300-141. (c) Back scattered electron image of GPT'03 300-42. (d) Back scattered electron image of the outermost layer of GPT'03 300-141. (e) FTIR ATR spectra. * indicates the peaks linked with the organic fraction, $\mathbf{\Delta}$ indicates the peaks connected with calcite, and $\bullet$ indicates the peaks linked with silicates composing the ochre. (f) Raman spectra. I = massicot from GPT'03 300-42; ii = goethite from GPT'03 300-42; iii = celadonite from GPT'03 300-141. 


\subsection{Green}

A multi-layered plaster from the outermost surface of a section of octagonal semi-pillar (GPT'03 300-141), characterized by an intense emerald green, was addressed (Figure 5b). The sample showed a succession of white ground layers with several superimposed colorations. The outermost green layer (Figure 5b,d) was composed of green earth (mainly celadonite, peaks at 174, 202, 279, 390, $459,544,606,701,3562$, and $3604 \mathrm{~cm}^{-1}$; EDS peaks of $\mathrm{K}$, Si, Al, Mg, and Fe; FTIR absorption bands at 975,1075 , and $3600 \mathrm{~cm}^{-1}$ ) (Figure $5 \mathrm{~d}-\mathrm{f}$ ).

\subsection{Ground Layers}

A portion of white layer, probably the ground layer for subsequent decoration, was sampled from a decorated double arch (GPT'03 300-4b) (Figure 4b). The micro-texture evidenced three overlapping layers (Figure $4 \mathrm{~d}$ ), determined as $\mathrm{Ca} / \mathrm{Mg}$ carbonate layers (see also, the Raman spectrum, Figure $4 \mathrm{e}$ ), with minor occurrences of silicates and Fe-oxides. The same composition characterized the ground layers in GPT'03 300-141.

\subsection{Binders}

FTIR spectrometry results supported the observations inferred from micro-textural analysis. The spectra of the majority of the samples preserved traces of organic binders (C-H stretching vibrations around $2900 \mathrm{~cm}^{-1}$; Figure 2g, Figure 3g, Figure 4e, Figure 5e, and Figure 6). In particular, by computer based modifications, it was possible to subtract the signal of the inorganic fraction (i.e., mainly calcite and azurite) from the spectra of sample GPT'03 300-9 (Figure 6), improving the signal of the absorptions due to lipoid chains (esters-triglycerides absorption at $1730 \mathrm{~cm}^{-1}$ ) and proteinaceous materials (amides transitions at 1600 and $1300 \mathrm{~cm}^{-1}$ ).

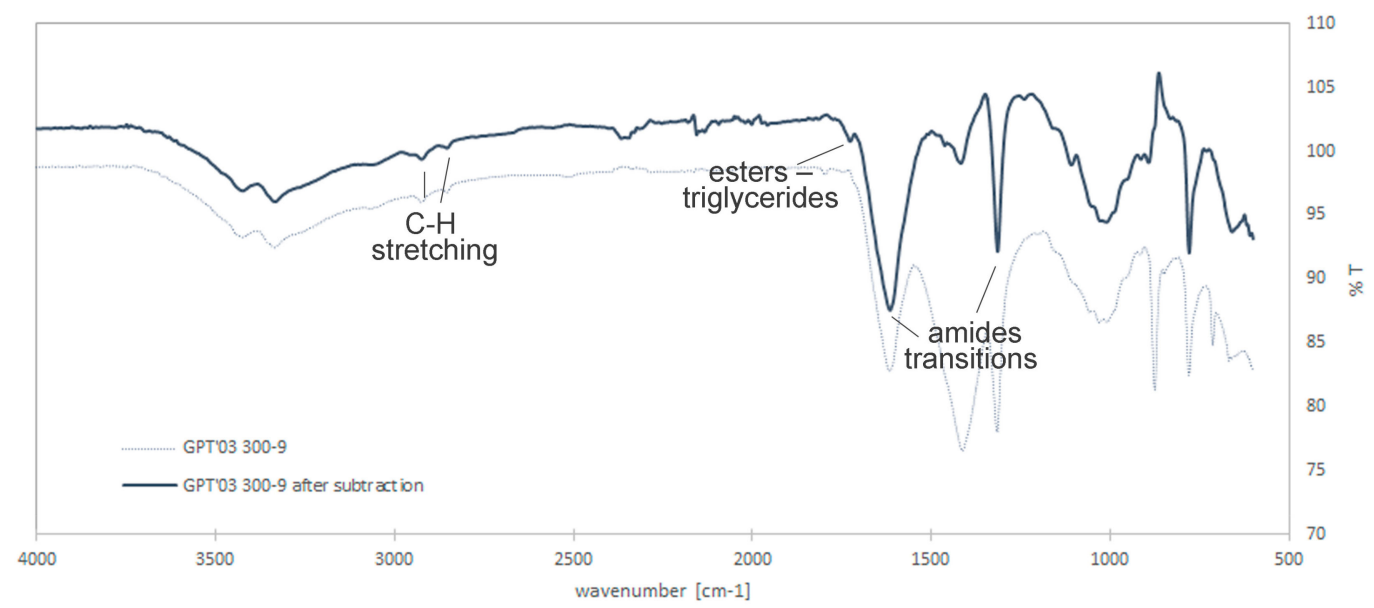

Figure 6. FTIR spectra of GPT'03 300-9. Comparison between the original spectrum and that originated by software after carbonate subtraction.

\subsection{Weathering Products}

Secondary processes as precipitation of halite, gypsum, and secondary calcite on the surfaces of the majority of the pieces were inferred by SEM-EDS (Figure 7a,b). Moreover, in GPT'03 300-42a, a crust of Ca oxalates (weddellite or whewellite) occurred between the pictorial coat and the marble substrate (Figure 7c). 

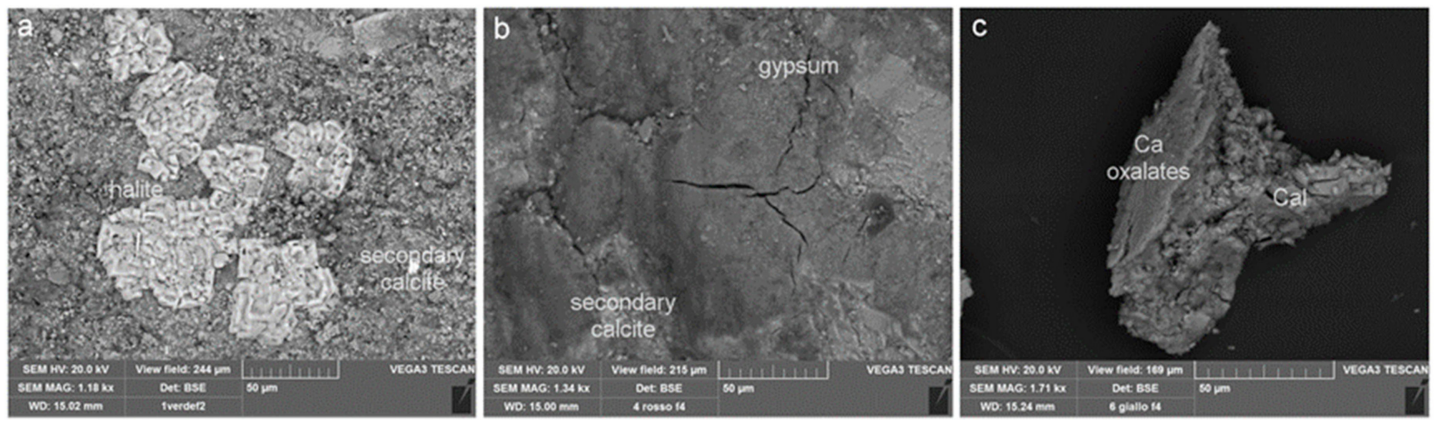

Figure 7. Weathering products. Back scattered electron images: (a) Halite and secondary calcite on the surface of GPT'03 300-141. (b) Powders of gypsum and secondary calcite on the surface of GPT'03 300-04. (c) Calcium oxalate crust between the marble substrate and the yellow paint layer in GPT'03 300-42.

\section{Discussion}

\subsection{Blue}

Blue paint layers proved to be made up mainly of azurite. This mineral has been used as a pigment since antiquity, and several extraction sites are documented. Antique treatises report that copper carbonate was extracted mainly in Hungary and Germany, and in Chessy (near Lyon, France), Sardinia, and Tuscany (near Siena, Italy) [5,26-28]. The occurrence of accessory monazite and clinoatacamite, malachite, barite, and mixite, associated with azurite in the addressed paint layers were used to infer a plausible pigment provenance $[29,30]$. The associated atacamite and clinoatacamite can be interpreted as intentional additions to the mixture, accessory minerals proxies of the ore deposit, or weathering product [31]. In fact, the chlorides, atacamite and clinoatacamite, already used as pigments by Egyptians and easily synthetized by alchemic processes, originate naturally in the azurite deposits and, after pigment application, as weathering products in the presence of $\mathrm{Cl}$ compounds. Also, the rare grains of malachite associated with azurite in natural outcrops and originating as its natural decay product in wet environments, could be naturally associated to calcite or intentionally added to obtain a desired color. Mixite has already been found in Italian artworks as impurity associated with azurite [28,30] and hypothesized as a provenance indicator [30]. By joining the historical data of the coeval technical essays, and its occurrence with azurite, the possible provenance for the pigment was restricted to Germany, Hungary, and, probably, the Czech Republic [30,32]. Moreover, the presence of monazite grains, a ubiquitous mineral phase, and pyromorphite could provide provenance indications, although no literature is reported. However, coupling historical data and mining information $[5,27]$, and considering the mineralogical association of azurite, lead minerals, and monazite, Sardinia is a possible source [33].

The match between the analysis of the paint layers of GPT'03 300-44 and GPT'03 300-98 suggests that the fragments are part of the same decorative piece, as already hypothesized after the stylistic analysis.

\subsection{Red}

Various ochres were identified as major components of red and pink paint traces. This type of pigment has been widely employed for centuries across Europe, due to its widespread availability in nature. Recent studies [34] linked mineral impurities and Raman peak shifting to ochre provenance: red ochre rich in hematite and magnetite with quartz impurities were related with a provenance from France (Puisaye or Vaucluse [34]). Conversely, barite impurities were recently associated with ochre deposits from the Ligurian area [35]. 


\subsection{Black}

Since antiquity, carbon blacks have been widely used. In fact, their simple production processes mean they can be produced locally, reflecting the culture and environment of each region [21]. The relative intensity of the peaks and the position of the secondary peaks suggest that the pigment applied was vine black [36,37], widespread in the Mediterranean region. It is likely that combusted vegetal remains, probably vine, were added to red ochres (in GPT'03 300-51) and azurite (in GPT'03 300-9) to produce darker shades.

\subsection{Yellow}

Analytical results on GPT'03 300-42a agree with Middle Age essays on pictorial art, where the reported yellow pigments were yellow ochre, orpiment, and lead based pigments including litharge, massicot, and lead-tin yellow. The alchemic synthesis for these pigments does not allow useful hints in provenance assessment.

\subsection{Green}

Green earths originate in glauconite and/or celadonite [38,39], associated with different geological environments. In fact, celadonite occurs as an alteration of basaltic rocks, whereas glauconite is derived from alteration of marine clays and sandstones [31,40,41]. Based on historical art supply data from the coeval technical essays, mineral identification helped in inferring provenance for the used green earth pigments. Spectroscopic techniques allowed the identification of celadonite as the major/sole component of the pigment [38]. Therefore, two provenance sites, assessed extraction localities for celadonite from antiquity to the present day, are possibly Mount Baldo (Verona, Italy) and Cyprus (Greece).

\subsection{Ground layers}

The exposed ground layer was analyzed in GPT'03 300-4b. The results of EDS microanalyses are comparable with those of the local production of lime mortar. In fact, since the Middle Ages in Genoa, quarries and furnaces for lime production were active in the area of Mount Gazzo (Sestri Ponente, Genoa) [42]. The production exploited the Triassic dolostone formation that also contains traces of $\mathrm{Si}$, $\mathrm{Al}$, and $\mathrm{Fe}$, as found in the addressed samples [42].

\subsection{Binders}

The FTIR spectrometry evidenced the joint occurrence of lipoid chains and amides, as in previous studies [8]. The signal due to the organic fraction is weak compared to that of the pigment, probably due to ageing of the lipoid and protein structures of the binder. In fact, the chemistry of the substrate (i.e., calcium carbonate) and the nature of the pigments (e.g., copper carbonate, lead oxide, etc.) can induce chemical reaction on the organic medium [43].

\subsection{Weathering Products}

Most pieces show superficial accretional weathering (gypsum and secondary calcite) whose origin cannot be assessed, as the outdoor exposure for 500 years and the burial time interval could both have contributed [20].

In GPT'03 300-42a, a crust of oxalates probably originated from the reaction between the marble substrate and the decomposed organic fraction, in turn derived from the interaction between the lipoid-proteinaceous binder and the metal oxide pigment (massicot) [11,16,44]. 


\section{Conclusions}

The multi-technique approach allowed the characterization of the ground layers and the pigment relics of the pictorial layers. The first are usually composed of locally-produced lime, but, herein, no organic binder was preserved enough to be characterized. Conversely, although extremely aged, it was possible to assess that pigments were mixed with lipo-proteinaceous binders.

Even if the monastic complex was relevant in Genoa during medieval times, no valuable pigments, such as cinnabar or natural ultramarine, were identified. A possible reason for this is the fact that it was a Franciscan monastery vowed to poverty, or that the analyzed paint relics were found on ornamental fragments and not on statues or on fine decorations.

The lack of evidences for local sources of azurite, green earths, or massicot supports the fact that these art supplies were imported along the many maritime trade routes connecting the Genoa harbor to the rest of Europe, the coast of the Mediterranean up to the Black sea, and the Far East [45].

The two different mineralogical associations with azurite suggest that the pigment had different origins, pointing to a thriving market of art supplies during the Middle Ages. The lack of archive information on pigment trades during the Middle Ages, and the scarcity of mineralogical studies describing the extraction sites for art materials, make it difficult to definitively recognize the provenance of the analyzed pigments. However, based on the analytical and bibliographical data, it is possible to claim that the city of Genoa was a trade destination for both continental routes (Hungary and France) and maritime commerce (Sardinia, Cyprus, and Veneto).

Author Contributions: Conceptualization, E.V., S.S., and L.G.; methodology, S.S. and L.G.; validation, S.S. and L.G.; investigation, E.V. and S.S.; resources, L.G. and S.S.; data curation, S.S. and E.V.; writing-original draft preparation, S.S. and L.G.; writing—review and editing, S.S. and L.G.; supervision, L.G.; funding acquisition, L.G..

Funding: This research profited from the financial support of the "Analisi delle proprietà microstrutturali, chimico-fisiche di materiali inorganici; determinazioni quantitative della composizione mineralogica di materiali naturali e delle proprietà tecniche dei materiali litici" Laboratory funds, DISTAV, University of Genoa, Italy.

Acknowledgments: The authors thank the Italian Ministry of Cultural Heritage through the Superintendence of Archaeology, Fine Arts, and Landscape for the metropolitan city of Genoa and the provinces of Imperia, La Spezia and Savona for granting access to the repositories of San Francesco di Castelletto pieces. M. Scambelluri made available the $\mu$ Raman laboratory at DISTAV. L. Negretti supported the SEM-EDS analyses and W. Sgroi made the FTIR ATR analyses.

Conflicts of Interest: The authors declare no conflict of interest.

\section{References}

1. Bradley, M. The importance of colour on ancient marble sculpture. Art Hist. 2009, 32, 427-457. [CrossRef]

2. Rossi-Manaresi, R.; Tucci, A.; Grillini, G.C.; Nonfarmale, O. Polychromed sculptures by Antelami in the Baptistry of Parma. Stud. Conserv. 2014, 31, 66-71. [CrossRef]

3. Di Fabio, C. Architettura polimaterica e accorgimenti percettivi, policromia della scultura e uso delle immagini nella cattedrale di Genova agli inizi del XIII secolo. In Proceedings of the Medioevo l'Europa delle Cattedrali, Parma, Italy, 19-23 September 2006.

4. Rinaldi, S. Storia delle Tecniche dell'arte. Materiali e Metodi della Pittura e della Scultura; Carrocci: Udine, Italy, 2011.

5. Cennini, C. Il Libro dell' Arte; Dover Publications: New York, NY, USA, 1954.

6. Nord, A.G.; Tronner, K. Analyses of paint from portals and murals in five medieval churches in Gotland. Fornvaennen 2014, 109, 118-126.

7. Fassina, V. The Arca Scaligera of Cansignorio della Scala by Bonino da Campione: Cleaning of the polychrome and gilded decorations. In Proceedings of the international conference LACONA VII, Madrid, Spain, 17-21 September 2007.

8. Pinna, D. Casi di Policromia nella Scultura Medievale in Emilia. Il Colore nel Medioevo: Arte, Simbolo, Tecnica; Andreuccetti, P.A., Lazzareschi Cervelli, I., Eds.; Istituto Storico Lucchese, Collana di Studi Sul Colore: Lucca, Italy, 2009; pp. 103-110. 
9. Ronca, F. Protein Determination in Polychromed Stone Sculptures, Stuccoes and Gesso Grounds. Stud. Conserv. 1994, 39, 107-120. [CrossRef]

10. Roascio, S.; Zucchiatti, A.; Prati, P.; Cagnana, A. Study of the pigments in medieval polychrome architectural elements of "Veneto-Byzantine" style. J. Cult. Herit. 2002, 3, 289-297. [CrossRef]

11. Bordignon, F.; Postorino, P.; Dore, P.; Tabasso, M.L. The Formation of Metal Oxalates in the Painted Layers of a Medieval Polychrome on Stone, as Revealed by Micro-Raman Spectroscopy. Stud. Conserv. 2014, 53, 158-169. [CrossRef]

12. Edwards, H.G.M.; Newton, E.M.; O'Connor, S.; Evans, D. FT-Raman spectroscopic analysis of pigments from an Augustinian friary. Anal. Bioanal. Chem. 2010, 397, 2685-2691. [CrossRef]

13. Nord, A.G.; Tronner, K.; Billström, K.; Belzacq, M.G. Pigment traces on medieval stonework in Gotland's churches-examination of seven 12th century baptismal fonts and a limestone pew. Fornvannen 2016, 111, $17-26$.

14. Arjonilla, P.; Domínguez-Vidal, A.; de la Torre López, M.J.; Rubio-Domene, R.; Ayora-Cañada, M.J. In situ Raman spectroscopic study of marble capitals in the Alhambra monumental ensemble. Appl. Phys. Mater. Sci. Process. 2016, 122, 1014. [CrossRef]

15. Papliaka, Z.E.; Philippidis, A.; Siozos, P.; Vakondiou, M.; Melessanaki, K.; Anglos, D. A multi-technique approach, based on mobile/portable laser instruments, for the in situ pigment characterization of stone sculptures on the island of Crete dating from Venetian and Ottoman period. Herit. Sci. 2016, 4, 1-18. [CrossRef]

16. Casadio, F.; Colombo, C.; Sansonetti, A.; Toniolo, L.; Colombini, M.P. Polychromy on stone bas-reliefs: The case of the basilica of Saint-Ambrogio in Milan. J. Cult. Herit. 2005, 6, 79-88. [CrossRef]

17. Campos-Suñol, M.J.; De la torre-Lopez, M.J.; Ayora-Cañada, M.J.; Dominguez-Vidal, A. Analytical study of polychromy on exterior sculpted stone. J. Raman Spectrosc. 2009, 40, 2104-2110. [CrossRef]

18. Sansonetti, A.; Bugini, R.; Biondelli, D.; Striova, J.; Colella, M. Painting Layers on Stone: Study of an Early Middle Ages High-Relief. In Proceedings of the 9th International Conference on NDT of Art, Jerusalem, Israel, 25-30 May 2008.

19. Weeks, C. The 'Portail de la Mere Dieu' of Amiens Cathedral: Its Polychromy and Conservation. Stud. Conserv. 1998, 43, 101-108.

20. Scrivano, S.; Gaggero, L.; Volpe, E. Methodological approach to reconstructing lost monuments from archaeological findings: The San Francesco di Castelletto church in Genoa. Minerals 2019, 9, 569. [CrossRef]

21. Bevilaqua, N.; Borgioli, L.; Adrover Gracia, I. I Pigmenti Nell'arte Dalla Preistoria alla Rivoluzione Industriale; I Talenti; Il Prato: Saonara, Italy, 2010.

22. CAMEO. Conservation and Art Materials Encyclopedia Online. Available online: http://cameo.mfa.org/wiki/ Forbes_Pigment_Database (accessed on 5 October 2019).

23. RRUFF Database. Available online: http://rruff.info/index.htm (accessed on 5 October 2019).

24. IRUG Spectral Database. Available online: http://www.irug.org/search-spectral-database (accessed on 5 October 2019).

25. Frost, R.L.; Čejka, J.; Sejkora, J.; Jakub, J.P.; Bahfenne, S.; Palmer, S.J. Raman microscopy of the mixite mineral $\mathrm{BiCu}_{6}\left(\mathrm{AsO}_{4}\right)_{3}(\mathrm{OH})_{6} \cdot 3 \mathrm{H}_{2} \mathrm{O}$ from the Czech Republic. J. Raman Spectrosc. 2010, 41, 566-570. [CrossRef]

26. Gettens, R.J.; Fitzhugh, E.W. Azurite and Blue Verditer. Stud. Conserv. 2006, 11, 54.

27. Eastaugh, N.; Walsh, V.; Chaplin, T.; Siddal, R. Pigment Compendium. A Dictionary and Optical Microscopy of Historical Pigments; Elsevier Butterworth-Heinemann: Oxford, UK, 2008.

28. Aru, M.; Burgio, L.; Rumsey, M.S. Mineral impurities in azurite pigments: Artistic or natural selection? J. Raman Spectrosc. 2014, 45, 1013-1018. [CrossRef]

29. Smieska, L.M.; Mullett, R.; Ferri, L.; Woll, A.R. Trace elements in natural azurite pigments found in illuminated manuscript leaves investigated by synchrotron X-ray fluorescence and diffraction mapping. Appl. Phys. A Mater. Sci. Process. 2017, 123, 1-12. [CrossRef]

30. Berrie, B.H.; Leona, M.; McLaughlin, R. Unusual pigments found in a painting by giotto (c.1266-1337) reveal diversity of materials used by medieval artists. Herit. Sci. 2016, 4, 1-9. [CrossRef]

31. Siddall, R. Mineral Pigments in Archaeology: Their Analysis and the Range of Available Materials. Minerals 2018, 8, 201. [CrossRef]

32. Mixite. Available online: https://www.mindat.org/min-2730.html (accessed on 4 October 2019). 
33. Calabona Mine (Alghero, Sardinia, IT). Available online: https://www.mindat.org/loc-2120.html (accessed on 4 October 2019).

34. Froment, F.; Tournié, A.; Colomban, P. Raman identification of natural red to yellow pigments: Ochre and iron-containing ores. J. Raman Spectrosc. 2008, 39, 560-568. [CrossRef]

35. Rellini, I.; Cabella, R.; Maggi, R.; Martino, G.; Firpo, M. An investigation into ochres from Arene Candide cave: Implications for mineralogical properties and provenance studies in the Liguria region. In Proceedings of the Individual abstracts of the SAA 84th annual meeting, Albuquerque, NM, USA, 20-27 June 2019; p. 999.

36. Coccato, A.; Jehlicka, J.; Moens, L.; Vandenabeele, P. Raman spectroscopy for the investigation of carbon-based black pigments. J. Raman Spectrosc. 2015, 46, 1003-1015. [CrossRef]

37. Cosentino, A.; Caggiani, M.C.; Cosentino, A.; Mangone, A. Pigments Checker version 3.0, a handy set for conservation scientists: A free online Raman spectra database. Microchem. J. 2016, 129, 123-132.

38. Moretto, L.M.; Orsega, E.F.; Mazzocchin, G.A. Spectroscopic methods for the analysis of celadonite and glauconite in Roman green wall paintings. J. Cult. Herit. 2011, 12, 384-391. [CrossRef]

39. Coccato, A.; Bersani, D.; Coudray, A.; Sanyova, J.; Moens, L. Raman spectroscopy of green minerals and reaction products with an application in Cultural Heritage research. J. Raman Spectrosc. 2016, 47, 1429-1443. [CrossRef]

40. Grissom, C.A. Green Earth. In Artists' Pigment. A Handbook of their History and Characteristics; Feller, R.L., Ed.; A Publication of the National Gallery of Art; Oxford University Press: Washington, DC, USA, 1994; Volume I.

41. Hradil, D.; Piskova, A.; Hradilova, J.; Bezdicka, P.; Lehrberger, G.; Gerzer, S. Mineralogy of Bohemian green earth pigment and its macroanalytical evidence in historical paintings. Archaeometry 2011, 53, 563-586. [CrossRef]

42. Vecchiattini, R. Minere di calcina in abondanza et in perfettione quanto habbia qualonque altra regione in Italia: Il Monte Gazzo a Genova-Sestri Ponente. Archeol. Postmedievale 2014, 17, 145-154.

43. Duce, C.; Bramanti, E.; National, I.; Ghezzi, L.; Bernazzani, L. Interactions between inorganic pigments and proteinaceous binders in reference paint reconstructions. Dalt. Trans. 2012, 42, 5975-5984. [CrossRef]

44. Cariati, F.; Rampazzi, L.; Toniolo, L.; Pozzi, A. Calcium Oxalate Films on Stone Surfaces: Experimental Assessment of the Chemical. Stud. Conserv. 2000, 45, 180-188.

45. Greif, A. On the Political Foundations of the Late Medieval Commercial Revolution: Genoa during the Twelfth and Thirteenth Centuries. J. Econ. Hist. 1994, 54, 271-287. [CrossRef] 